\title{
Conservation Models for Sayur Babanci as A Potential Culinary Tourism of Betawi
}

\author{
Lila Muliani ${ }^{1}$, Munir Saputra ${ }^{2}$ \\ \{lilamuliani@gmail.com ${ }^{1}$, muniraaa.ms@gmail.com ${ }^{2}$ \} \\ Institut Ilmu Sosial dan Manajemen Stiami, Jakarta, Indonesia ${ }^{1,2}$
}

\begin{abstract}
This research objectives are 1. Identify strenghts and weakness of Sayur Babanci (SWOT analysis) 2. Propose some conservation models to develop Sayur Babanci. The result shows that 1. Indeed, Sayur Babanci is a traditional Betawi cuisine that almost extinct. This dish is not widely known by the society, especially by the younger generation. Restaurants or stalls that serve Sayur Babanci in Jakarta and the surrounding areas are very limited in number. 2. Indeed, Sayur Babanci have to be conserved as a traditional heritage of Betawi in term of culinary aspect. Sayur Babanci has many strenghts to be pointed as one of Betawi culinary icon which potential to attract touriste ${ }^{\mathrm{s}} \mathrm{s}$ attention. It has good nutritional content, health benefit of the spices and herbs, and also high cultural and philosophical value. 3. Conservation models that appropriate for Sayur Babanci are developing standard recipes and documentation, designing comprehensive and creative story telling, transfer knowledge, and series actions of promotion.
\end{abstract}

Keywords: Betawi Traditional Food, Betawi Ethnics, Sayur Babanci.

\section{Introduction}

Traditional food is closely related to the tradition. All the aspects of traditional food is part of the cultural heritage of society. Each society has its own traditional culture, including traditional foods, with different types of ingredients, cooking techniques, and serving suggestions.

Term of traditional foods refer to the food that are passed through generations, have a distinctive taste that matches to local palate, have no contradiction with local belief and religion, and made from local ingredients which originating and easily found around the environment (Sastroamidjojo, S., 1995), traditional foods could also be symbol of pride for the local society (Salfarino, R., 2015)

Local food is associated with two descriptors of sustaible agriculture, which are environmentally friendly and supporting local economy (Saleh, I., 2012). Thus, the higher people ${ }^{e c}$ interest and demand for the traditional food, local economy should be growing better since the materials and supporting material for the foods are coming from its local environment. More over, opportunity for the culinary businessess will be more developed.

Unfortunately, globalization and modernization are slowly reducing the people ees interest, especially the younger generation, towards traditional foods. Western food seems more appetizing and more desirable for the reasons of practical, modern, and prestigious. This kind of modernization and globalization could bring the traditions marginalized and slowly become 
vanished. No doubt that in the current situation, most of the younger generation are more familiar to western foods rather than its own traditional foods.

In Jakarta, for instance. Betawi ethnic as indigineous people of Jakarta, actually has various of delicious traditional food. Ironically, finding Betawi traditional foods in its own place, Jakarta, is not as easy as finding western food. Restaurants or food stalls that specialized in serving Betawi traditional food is very limited in number, and the dishes that is served is less varied. That is the reason why most people only familiar to Nasi Uduk, Kerak Telor, and Soto Betawi. At the end, younger generations would never know the variety of Betawi traditional food.

About $76 \%$ in average, teenagers in Jakarta not really know about traditional food of Betawi, except the iconic dishes such as Kerak Telor and Soto Betawi (100 Mak Nyus Jakarta, 2015). Whereas, Betawi tradition has many kind of dishes with variety of tastes due to influences from several ethnics, from China, Middle East, Malay, India, to Europe, which somehow in the history have given ,color" in many aspects of Betawi culture, including the aspect of culinary. Beside the foreign influence, some local culture of Indonesia are also contributed to color the original of Betawi culture. Sundanese culture found to be the most influence.

One of Betawi traditional food which has uniqueness that represents the combination of several ethnic groups is Sayur Babanci. This dish could be categorized as a rare food since it is very hard to be found nowadays. Not even all Betawi people familiar to Sayur Babanci because as we know, Betawi ethnic has a very wide area deployment which can not be limited to the administrative area. Currently, Betawi ethnics spread to the Depok, Bogor, Bekasi, Cikarang and Karawang regions, which are now part of the West Java province, to Tangerang, which is now in the province of South Tangerang (Tangsel) and Banten province.

In fact, many of our traditional foods, not only Betawi, lately become rare and difficult to be found, or even some might become extinct. It is admitted that younger generation now mostly will choose fast foods rather than traditional foods (Nurhidayar, 2012). If this kind of situation continues, sooner of later Sayur Babanci could be dissapeared from its own home.

In tourism point of view, traditional foods could be one of the simplest way for tourists to explore the culture and heritage of a country. Food is also representing the geographic, history, culture, and habit of indigenous society. Food acts as a national identity (Reza, 2014). According to Inskeep, E. (1991), the quality and uniqueness of a food should become promotion tool for itself. The historical and cultural values are interesting for tourists. Traditional food must be served in the best quality so that tourists can taste and enjoy it.

This current fact becomes a strong reason to immediately do the action for conservation of Sayur Babanci. That is why the author concern to conduct research on The Conservation Models for Sayur Babanci as A Potential Culinary Tourism of Betawi, with the following formulas:

1. Identify strenghts and weakness of Sayur Babanci (SWOT analysis)

2. Propose some conservation models to develop Sayur Babanci

\section{Method}

This research is using qualitative approach which according to Anselm Strauss and Juliet Corbin is a reasearch that build the theory with no statistical procedure analysis. This research collects datas from various sources through interviews and observations, as well as such other 
sources like book, journals, and reputable digital news, to formulate some proposals of conservation models for Sayur Babanci so it ${ }^{\text {te }} \mathrm{s}$ not forgotten by the younger generation.

Grounded theory method used in this research enable researcher to analyze and interpret the datas to build the theory. The word theory is not only to examine the existing theories like in other research approach, but also to build a new theory. And grounded theory method applied to develop new theories from the datas obtained during the research.

To obtain theories that grounded, researchers have to work in the field during the study. Interview, observation, and other tools that is used to gain the datas should be recorded in detail. In this research, primary datas collected from direct observations, in depth interview, and FGD (Focus Group Discussion) with the experts and Betawi culinary practioners. While secondary is gathered from various documents. In depth interview with experts and practicioners in Betawi culture and culinary would provide more comprehensive inputs and suggestions to analyze the SWOT properties.

\section{Result And Discussion}

\subsection{History and Philosophy of Sayur Babanci}

Sayur Babanci is one of Betawi traditional food. It is verified since this food already meet the criterias to be categorized as traditional food that mentioned by Sastroamidjoji, S. (1995). The first criteria is passed through generations. According to the result of FGD, $\mathrm{Hj}$. $\mathrm{Cucu}$ Sulaicha - one of the culinary practicioner who is very familiar to this food - Sayur Babanci is a special dish for Lebaran Day in her big family. Her parent always cooked Sayur Babanci to celebrate the Eid Al-Fitr. Then, she continued the tradition to her own family. The same experience is also told by $\mathrm{Hj}$. Anisa Diah Sitawati - another Betawi culinary practicioner.

The second criteria is having a distinctive taste that matches to local palate. In the past, Sayur Babanci is a very popular dish that always comes during Lebaran. This food categorized as fancy food because it contains beef which always been a food with relatively high in price. The third criteria is having no contradiction with local belief and religion. It is obvious that Sayur Babanci has no contradiction to Islam religion since Betawi people majority are moslem. No prohibited ingredients which categorized as haram and it is served in Lebaran Day, one of the biggest and holy moslem day.

The last criteria is made from local ingredients which originating and easily found around the environment. This criteria is also fulfilled because some ingredients used in Sayur Babanci are very unique and not easily found in other traditional dishes, they are temu mangga, botor, kedaung, and tai angin. These four ingredients are very typical and contributed to the special palate of Sayur Babanci.

Sayur Babanci might not as popular as Sambel Godog atau Sayur Godog that is commonly served as Lebaran menu in most Betawi people ${ }^{\text {ee }}$ home. This dish might only found in some parts of Betawi area. As we know, Betawi ethnic group has a very wide distribution area. According to Yahya Andi Saputra - expert of Betawi culture and heritage at least there are three divisions of Betawi area, based on location and characteristic of the people, that are Betawi tengah/middle Betawi, Betawi pesisir/coastal Betawi, and Betawi pinggir/suburban Betawi. The different character of the people in each division is certainly affected by culture, eating habit, and its indigenous dishes. 
As mentioned by Anisa Diah Sitawati, Sayur Babanci is very familiar to people who lived around Cempaka Putih, Kemayoran, Kota, and Tanah Abang. Betawi people outside those areas might not know about this dish. It represents the comfort food of Betawi tengah people.

Although it is called Sayur Babanci (sayur means vegetables in Indonesian), this dish does not contain vegetables at all. Anisa Diah Sitawati said that Sayur Babanci also known as Ketupat Babanci or Ketupat Sayur Babanci because it is always served with ketupat as Lebaran"es special dish.

In a bowl of Sayur Babanci, we could find at least three different cultural influences, which are Malay, Middle East, and local Betawi culture. Coconut milk that is used as the ingredient represents Malay culture, spices such as cumin represents Middle East, and distinctve spices such as temu mangga, botor, kedaung, and tai angin represent the Betawi culture.

Beef is the main ingredient of Sayur Babanci, cooked with various spices and herbs. Some people say that the word Babanci is given because of the „,behavior ${ }^{\text {ee }}$ of this food which difficult to be identified. It is not gulai, not also kare nor soto (Indonesia Kuliner, A., 2016). $\mathrm{Hj}$. Cucu Sulaicha mentioned that the word Babanci is given because this dish uses young coconut meat that is commonly used for sweets, such as drinks or puddings. Another version said that the word Babanci might be derived from combination of Babah - Cici or Babah Enci, because some people assumed that Sayur Babanci was once cooked by Chinese descent.

Sayur Babanci has high philosophical values. One of them could be seen from its function as a typical dish that is always served in Lebaran day. It is a mandatory to enjoy Sayur Babanci with ketupat. This fact describes that Sayur Babanci was representing Moslem Betawi society because ketupat is a symbol of celebrating Islamic great day that has become a tradition since the reign of Demak was led by Raden Patah in the 15th century.

Ketupat itself is a symbol of apology and blessing since in tradition it is served in the Eid Al-Fitr, the victory day, after moslems having 30 days of fasting. In the Eid Al-Fitr all moslem should forgive each other. All the mistakes will be forgiven so everyone is back in pure and free from sins. Ketupat is also described as a symbol of retaining the lust and representing pure concience. The complicated woven of ketupat wrapper is reflecting various kind of human "e mistakes. The white color of rice cake inside is a reflection of cleanliness and purity of the heart after forgiving others (Rianti, dkk., 2018).

High philosophical values also comes from the coconut fruit that is used in Sayur Babanci. Coconut tree is one of the plant that symbolizes the prosperities, because once it is fruiting the yield are quite alot. Almost every part of the coconut tree can be utilized. From all the ingredients of Sayur Babanci, four of them come from coconut tree. They are young coconut meat, coconut water, coconut milk, and grated coconut. Those four coconut ingredients not only contribute to enrich the delicious taste of Sayur Babanci but also prove that Sayur Babanci is indigenous food from Betawi. In the history, Betawi land that geographically located near the beach is ovegrown with coconut trees and that is why this land called Sunda Kelapa.

\subsection{Nutritional Content and Benefit of Sayur Babanci}

The taste of Sayur Babanci is as delicious as other traditional food of Betawi. Perfect blend of sweet, hot, and savory taste has created a faultless combination. Sweet tones from coconut water, young coconut meat, and coconut milk are blent with the hot of chili and spices and the savory of coconut milk and grated coconut.

The combination of spices creates complexity but harmonious blend of flavor. The use of spices in sufficient amount could be a secret recipe for delicacy but it could also be a flavor 
destroyer if the composition of spices are not appropriate. Too many spices or disharmonious of spices used in a dish will make the food tastes like jamu (herbal drinks).

Among all the ingredients used in Sayur Babanci, there are four names that less common to the kitchen of most people. They are temu mangga, botor, kedaung, dan tai angin. Altough those names sound strange but there are no strange taste detected in Sayur Babanci. This all because of the right compotition and proper cooking technique. Botor, kedaung, and tai angin must be roasted first before they are grounded and mixed into the dish.

To roast those ingredients, patience and experiences are most needed. Roasting means cooking without oil. Just like people roast coffee bean before grounded, some spices and ingredients also need to be roasted. This thermal process is useful to bring out and strenghten the aroma (Syamsir, E., 2011). People with no experience in roasting process could make the spices burnt and become bitter. Of corse it will also affected the taste of the dish. For Sayur Babanci, roasting process is also done for grated coconut before it is grounded. Roasting process will change the color of grated coconut to brown.

Beside its delicious taste, Sayur Babanci also provides good nutrients. Beef as a main ingredient is a source of protein and fat with quite complete amino acid composition. That is the reason why beef becomes one of the qualified protein source. Our body needs protein for growth and development. Beef also rich in iron $(\mathrm{Fe})$ that is needed to prevent anemia. Coconut milk is a source of fat, coconut water supply minerals and carbohydrate, and the young coconut meat is a good source of fiber that very useful for digestive system.

Talking about benefit of Sayur Babanci, it will certainly talk about the herbs and spices used as the ingredient. Not only to generate the flavor, herbs and spices contain several active compounds that act as antimicrobial, antioxidant, and other benefits that are good for health. People can easily find scientific references about benefit of herbs and spices that commonly used in the kitchen.

Among 16 herbs and spices used in Sayur Babanci ingredients, kedaung, botor, and tai angin are not as popular as others. The seed of kedaung is commonly used in herbal industry as jamu. It has antibacterial properties and commonly used in traditional medicine to treat infections and stomach disorders. Tai angin has characteristic that is believed to heal colds, sprue, and dysentery. Whereas botor is the name for kecipir (winged bean) seeds. It is commonly used as medicine for ear inflammation, colds, rheumatic, malaria, poor digestion, and high blood sugar level (Gardjito, M., dkk., 2017)

\subsection{Formulating the Right Conservation Models}

To obtain a better picture of conservation models that suit to Sayur Babanci, SWOT analysis is required to capture the streghts, weaknesses, oportunities, and threats of it. The formulations in this SWOT analysis are concluded from the result of literature study and FGD that had been conducted with competent experts as source persons. The following are the result that are formulated by the author:

\section{Strenghts:}

1. Delicious and have good nutritional contents

2. Having cultural and philosophical value

3. Unique with distinctive taste of typical herbs and spices of Betawi

4. Mixture of 3 different cultural background

\section{Weaknessess:}

1. Using a lot of herbs and spices so it gives the impression of complexity and impratical 
2. Difficult to find

3. Not widely known by most people

4. The recipe is not easy to be found and the references are limited

\section{Opportunities:}

1. Potential to be one of Betawi culinary icon with philosophical value behind.

2. Potential to get touristes attraction because of the use of various herbs and spices, including the rare ones, and all the benefits inside. This could be packed into a nice story telling.

\section{Threats:}

1. Must be able to compete with western food, especially among the young generation that has lack of information about the variety of Betawi traditional food.

2. The availability of its distinctive and rare herbs and spicess in the market.

Referring to the SWOT analysis above, some steps to do to preserve the availability of Sayur Babanci in the society are:

1. Establish standard recipe as a guidance in documenting the recipe and step by step to make Sayur Babanci. This standard recipe should be published to the public so everyone could make it as a trustworthy reference.

2. Regularly conduct the transfer knowledge activities on how to make Sayur Babanci using the published standard recipe. It is intended to make as many as people aware about Sayur Babanci. One of the activity that should be match to the goal is cooking demo or training. And at a time doing sampling to the audience, so everyone can taste the delicious of Sayur Babanci.

3. Creat an interesting story telling to describe the uniqueness of Sayur Babanci that have philosohical values and consists of various herbs and spices that have good benefit for health. This story telling should be published in various media channel in a creative, innovative, and up to date packaging to attract the young generation as target market.

4. Promote Sayur Babanci as one the icon of Betawi traditional food by introducing it to every major cultural event held in Jakarta.

Conservation models that formulated above are in line with the form of cultural conservation concept by Imvarica, F. (2013), which are Culture Experience and Culture Knowledge. Culture Experience is a conservation concept conducted to suitable to applicate Culture Experience concept. Experiencing the live cooking technique, seeing and smelling the aroma of herbs and spices used for Sayur Babanci, will be an exciting experience.

While, Culture Knowledge is a pace taken to educate the public by creating a cultural information centre to provide information for tourism. In this Culture Knowledge concept, conservation models that suitable for Sayur Babanci is creating complete documentations that not only contain of recipe but also an interesting story telling. This documentation should be made in creative and innovative packaging to grip attention from younger generation.

However, all that conservation efforts will be useless and imposible to be done only by the author of this acticle. Conservation actions could not last longer and develop optimally without full support from the government and the society. The role of the goverment is crucial in supporting this conservation steps. For instance, by encouraging the restaurant"s owner, Betawiees food stalls, and hotels in Jakarta to provide Sayur Babanci in the menu list. 
The sustainability of Sayur Babanci is depend on the people who still want to enjoy it. But, how to make people enjoy it if they didn ${ }^{e t}$ know anything about this pacticular dish? We centainly need to introduce and promote Sayur Babanci to be known by society. Increasing the interest of Sayur Babanci will effect the availability of its unique spices and ingredients on the market and at the end will increase the restaurants or stalls that serve it as their regular menu. Just like the law of supply-demand theory, the supply will be increasing as the demand increase.

Following are the conclusions of the research above:

1. Indeed, Sayur Babanci is a traditional Betawi cuisine that almost extinct. This dish is not widely known by the society, especially by the younger generation. Restaurants or stalls that serve Sayur Babanci in Jakarta and the surrounding areas are very limited in number.

2. Indeed, Sayur Babanci have to be conserved as a traditional heritage of Betawi in term of culinary aspect. Sayur Babanci has many strenghts to be pointed as one of Betawi culinary icon which potential to attract tourist"es attention. It has good nutritional content, health benefit of the spices and herbs, and also high cultural and philosophical value.

3. Conservation models that appropriate for Sayur Babanci are developing standard recipes and documentation, designing comprehensive and creative story telling, transfer knowledge, and series actions of promotion.

However, those conservation models could not be done optimally by one or two persons only. Conservation of the heritage will be effective if the object is still being used (Pitana, I.G., 2003).That is why Sayur Babanci has to be loved and enjoyed by as many people. Sayur Babanci have to be one of Betawies favorite food for many people, just like Nasi Uduk or Soto Betawi. To make Sayur Babanci will not be forgotten, its presence must continue to be available in the society. Support from the government, in this case is local DKI Jakarta goverment through Dinas Pariwisata, is extremely needed as:Motivator. To give motivation and burn the spirit of retaining the culinary heritage of Betawi traditional cuisine to all the restauranteur in Jakarta to serve Sayur Babanci as one of their restaurantes menu. Fasilitator. To give the opportunity and facility for Betawi society to conduct activities in supporting the conservation actions for Sayur Babanci, such as developing book of Betawi traditional recipes, organizing cooking demonstration and socialization of Sayur Babanci to the society

\section{Conclusion}

Following are the conclusions of the research above:

1. Indeed, Sayur Babanci is a traditional Betawi cuisine that almost extinct. This dish is not widely known by the society, especially by the younger generation. Restaurants or stalls that serve Sayur Babanci in Jakarta and the surrounding areas are very limited in number.

2. Indeed, Sayur Babanci have to be conserved as a traditional heritage of Betawi in term of culinary aspect. Sayur Babanci has many strenghts to be pointed as one of Betawi culinary icon which potential to attract touriste"s attention. It has good nutritional content, health benefit of the spices and herbs, and also high cultural and philosophical value. 
3. Conservation models that appropriate for Sayur Babanci are developing standard recipes and documentation, designing comprehensive and creative story telling, transfer knowledge, and series actions of promotion.

However, those conservation models could not be done optimally by one or two persons only. Conservation of the heritage will be effective if the object is still being used (Pitana, I.G., 2003).That is why Sayur Babanci has to be loved and enjoyed by as many people. Sayur Babanci have to be one of Betawie"s favorite food for many people, just like Nasi Uduk or Soto Betawi. To make Sayur Babanci will not be forgotten, its presence must continue to be available in the society. Support from the government, in this case is local DKI Jakarta goverment through Dinas Pariwisata, is extremely needed as:

1. Motivator. To give motivation and burn the spirit of retaining the culinary heritage of Betawi traditional cuisine to all the restauranteur in Jakarta to serve Sayur Babanci as one of their restaurant"s menu.

2. Fasilitator. To give the opportunity and facility for Betawi society to conduct activities in supporting the conservation actions for Sayur Babanci, such as developing book of Betawi traditional recipes, organizing cooking demonstration and socialization of Sayur Babanci to the society.

\section{Acknowledgement}

This study would not have been possible without the financial support from Management of Institut STIAMI and LPPM STIAMI as this is one of the reseach funded by Hibah Penelitian Internal Institut STIAMI, 2018-2019 period.

Highly appreciation and thankful also for Bang Yahya Andi Syaputra, Mpok Annisa Diah Sitawati, dan Nyak Cucu Sulaicha as source persons that shared all the information and datas needed for this study.

And I am grateful for the support from Dr. Euis Komalawati, S.Sos, M.Si as Dean of FISMA and Dr. Cundo Harimurti, S.T., M.Si. as Head of Hospiltality Study in Institut STIAMI so author could complete this study within the specified time period.

Special thanks also for Pak Murnir, as a partner in thus study, and of course to all the colleagus, Bu Fajar, Bu Heni, Bu Niny, and Pak Firman in Hospitality Study of Institut STIAMI.

\section{References}

[1]. Donna, Angelina Maria. 2009. Sayur Babanci, Masakan Kuno Yang Terpinggirkan. Melalui: <Megapolitan.Kompas.Com/Read/2009/08/24/08575516/Sayur.Babanci> [31/12/18]

[2]. Gardjito, Murdijati, Dkk. 2017. Profil Struktur, Bumbu, Dan Bahan Dalam Kuliner Indonesia. Gajah Mada University Press. Yogyakarta. Hal 115-116.

[3]. Indonesia Kuliner, Akademi. 2016. Kuliner Betawi, Selaksa Rasa Dan Cerita. Jakarta: Gramedia.

[4]. Imvarica, Faradya. 2013. Melestarikan Budaya. Pengembangan Karya Ilmiah Kurikulum Dan Teknologi Pendidikan, Fakultas Ilmu Pendidikan, Universitas Negeri Semarang.

[5]. Inskeep, Edward. 1991. Tourism Planning, An Integrated And Sustainable Development Approach, Van Nostrand Reinhold, Newyork, P.286.

[6]. Jacobus, Ranjabar. 2006. Sistem Sosial Budaya Indonesia Suatu Pengantar. Ghalia Indonesia. Bogor. 
[7]. Manuaba, Putera. 1999. Budaya Daerah Dan Jati Diri Bangsa: Pemberdayaan Cerita Rakyat Dalam Memasuki Otonomi Daerah Dan Globalisasi. Jurnal Masyarakat, Kebudayaan Dan Politik, Th Xii, No 4, Oktober 1999, 57-66.

[8]. Nurhidayat, 2012. Peluang Bisnis Makanan Tradisional Indonesia . Yogyakarta: Amikom Yogyakarta.

[9]. Rianti, Angelina, Dkk. 2018. Ketupat As Traditional Food Of Indonesian Culture. Nutrition And Food Technology Study Program, Faculty Of Life Science, Surya University, Tangerang, Banten, Indonesia. Journal Of Ethic Foods 5 (2018) 4-9.

[10]. Reza, Alberto. 2014. The Role Of Local Food In The Touristic Experience. Bachelores Thesis Degree Programme International Business. Tampere University Of Applied Science.

[11]. Saleh, Ismail. 2012. Sustainable Culinary Tourism In Puncak, Bogor. Tesis. Institut Pertanian Bogor (Ipb), Bogor.

[12]. Salvarino, Ryan. 2015. Makanan Tradisional Indonesia. Melalui: <Makanantradisionalsehat.Wg.Ugm.Ac.Id/2015/11/23/Makanan-Tradisional-Indonesia-2/> $[18 / 05 / 18]$

[13]. Sastroamidjojo, S. 1995. Makanan Tradisional, Status Gizi, Dan Produktivitas Kerja. Dalam Prosiding Widyakarya Nasional Khasiat Makanan Tradisional. Jakarta: Kantor Menteri Negara Urusan Pangan. Hal 62-66

[14]. Singleton, John, "Implication Of Education As Culture Transmision" Dalam George D. Spindler (Ed.), Education And Cultural Process (New York: Holt, Rinehart And Winston Inc., 1974).

[15]. Syamsir, Elvira. 2011. Penanganan Bumbu Dan Rempah. Melalui: <Ilmupangan.Blogspot.Com/2011/08/Penanganan-Bumbu-Dan-Rempah.Html> [31/12/18] 